\title{
Catastrophe Insurance, Capital Markets, and Uninsurable Risks
}

\author{
Dwight M. Jaffee \\ Haas School of Business \\ University of California \\ Berkeley, CA 94720-1900 \\ Tel: 510-642-1273 \\ Email: jaffee@ haas.berkeley.edu \\ Thomas Russell \\ Department of Economics \\ Santa Clara University \\ Santa Clara, CA 95053 \\ Tel: 408-554-6953 \\ Email: trussell@scuacc.scu.edu
}

The authors wish to thank Professors Sandra Chamberlain of the Leavey School of Business Santa Clara University, Ed Omberg of San Diego State University School of Business, and Roman Weil of the University of Chicago, seminar participants at the Wharton Financial Institutions Center and the Universite Aix/Marseille, and the two journal referees for helpful discussions. The usual disclaimer applies.

This paper was published in the Journal of Risk and Insurance, June 1997 


\section{Introduction}

Catastrophes, according to Zeckhauser [1995], "provide a principal justification for insurance. One pays premiums to secure financial protection against low-probability high-consequence, events - what we normally label catastrophes."

Principal justification or not, it is clear that private insurance markets are currently having a difficult time providing coverage for catastrophe risk. In California, for example, where earthquake coverage must be offered as an option on homeowner's policies, companies representing $93 \%$ of the homeowner's insurance market either stopped writing homeowner's insurance or imposed strict limits on the policies they were willing to sell after the Northridge earthquake in 1994. [California: Dept. of Insurance Survey May 1, 1995]

In Florida, insurance company withdrawal from the state has been prevented only by a legal moratorium on exit. In many states (e.g. California, Florida, Texas, Hawaii), public officials now take it for granted that if catastrophe insurance is to be available at all, it must be provided by a public agency either State or Federal.

Catastrophes have thus become what insurance textbook writers call an 'uninsurable risk'. The purpose of this paper is to examine what it is about catastrophe risk which makes it uninsurable. The paper argues that there is nothing in the nature of catastrophe risk as such which prevents the operation of a private market in insurance. In particular, large as the damage from a catastrophe event may be, it is infrequent, local, and unlikely to be correlated with the price of a global market index, so it is certainly diversifiable.

For example, even if every 20 years (on average) a $\$ 50$ billion earthquake occurs somewhere on one of California's many fault lines, ex ante we do not know where this event will occur. If we assume that say 5 million households are at risk from this event, it is sufficient for the insurance industry to collect an annual premium of $\$ 500 /$ household/year to break even. (Assuming for simplicity no allowance for administrative costs or time value of money). Taking the long view, risk sharing seems eminently possible in this case.

What then prevents the operation of a private market? We will argue that to be viable a private insurance market must solve not a 'point in time' risk spreading problem, but rather an intertemporal problem of how to match a smooth flow of annual premium receipts to a highly nonsmooth flow of annual loss payments. This is a capital market problem, not an insurance market problem, and we will argue that current institutional arrangements are not conducive to its solution. This, however, does not preclude a private market based on different institutional arrangements, and we examine some proposals which could allow private markets profitably to re-enter the catastrophe line. 


\section{Is Catastrophe Risk Uninsurable?}

We begin by considering the factors that cause market participants to consider catastrophe risks uninsurable. There seems to be no agreed upon definition of an uninsurable risk. The insurance literature, however, often identifies three factors which are viewed as impediments to the successful operation of a private insurance market:

1) Problems of adverse selection and moral hazard;

2) The insured risk is 'too large' in some sense;

3) The probability of loss is not susceptible to precise actuarial calculation.

These factors, however, do not seem sufficient to cause the failure of private markets in catastrophe insurance. With respect to adverse selection and moral hazard, the ex ante risk of catastrophic loss is not private information of the insured, and the insured agent has no control over the event creating the risk. ${ }^{1}$ Second, although insured catastrophe risks can be very large, the question can be raised of the size relative to other risks: for example a $1 \%$ change in the value of the New York Stock Exchange, a not infrequent event, is the same order of magnitude as a major catastrophe (about $\$ 70$ billion). Third, we will now argue that neither the size of the risk nor imprecise probability estimates have prevented the successful operation of risk-sharing markets in the past. ${ }^{2}$

Consider, for example, one of the oldest lines of business, marine insurance. Marine insurance could, in principle, generate large losses. A hurricane, or an act of war, could affect many ships at the same time. Moreover, accurate assessment of the probability of weather-related risks has only become available recently. Yet a market for marine insurance operated among the ancient Greeks and Phoenicians, and flourished in London from as early as the 17th Century.

What factors permitted the operation of a private market in marine insurance when prima facie this line suffers from the same 'uninsurable' characteristics, size and imprecision of risk, as earthquake insurance? The answer to this question lies in the particular institutional arrangements which marine insurers made for accessing capital markets in the event of a large loss.

These arrangements took two forms. In the older form, the so called contract of bottomry, a lender advanced the ship-owning merchant the full cost of the voyage as a loan. If the voyage was successful, the ship-owner repaid the bank at an interest rate which included a premium to reflect the risk of loss. If the ship was lost, the loan was forgiven.

\footnotetext{
${ }^{1}$ There may be ex post moral hazard problems with catastrophes, since losses may be hard to verify and claims may be inflated. Fraud, however, can be controlled by vigorous investigation and careful contracting can exclude coverage on those items where claim inflation is likely. Such actions would enable the basic market to function, albeit with some contractual limitations.

${ }^{2}$ This point seems to have first been made by Karl Borch [1990] who noted (p. 315) the emergence of viable private insurance arrangements for commercial aircraft and commercial satellite risk. Both of these lines involved potentially huge losses and neither had any history of loss from which to assess probabilities.
} 
In the second form, syndicate insurance ${ }^{3}$, say as practiced at Lloyds, a ship-owner's broker insured the hull and cargo with a Lloyds' syndicate of 'Names'. A 'Name' was an individual who had 'shown' the existence of substantial wealth. Each name pledged the full extent of this personal wealth in the settlement of potential losses.

Note that in both of these institutional arrangements the fund for settlement of losses was clearly defined. Indeed, in the case of the contract of bottomry, the fund for settlement of losses had already been advanced, and in this case there is no distinction between a bank and an insurance company.

The major question for modern catastrophe insurance companies is whether additional sources of capital--beyond the active capital provided by current investors--can finance the upper layers of catastrophic risk to enable the market to operate more completely, even in the case in which these high losses are expected. ${ }^{4}$ We turn now to an examination of why such a capital pool is needed and why it is so difficult to arrange.

\section{Catastrophe Insurance And Loss Ratios}

For most lines of insurance, the value of loss per dollar of insurance varies little from year to year. For that reason, a dynamic premium strategy, in which premiums are set so that the loss ratio (based on say the average of the last three years of loss) attains some target level, will produce a time path of premiums which is reasonably smooth. The actual current year loss ratio will also be reasonably smooth and will be close to the target. See e.g. Brockett and Witt [1982] and Venezian [1985].

In this case, it is both possible and appropriate for the company to plan to pay today's losses out of today's premiums. Of course, some capital is necessary to cover unexpected losses, but the unexpected losses will be small if the loss pattern is smooth, and in this case little capital is needed to cover the losses.

In contrast, in the case of catastrophe insurance, the annual pattern of losses is highly variable and dynamic premium strategies based on a few years of experience will lead to loss ratios in some years which are far from the target. In particular, in bad years a large amount of capital would be required to cover high losses. This point can be easily seen by examining Table 1, which shows the loss ratio over time by line, measured as a percent. For all lines except earthquake, the industry has been largely successful in keeping loss ratios below 1, (percent below 100). In the case of multiple peril crop and homeowners multiple peril the ratio did exceed 1 in several years

\footnotetext{
${ }^{3}$ It is argued by historians of insurance that the institutional arrangements changed from bottomry to syndicate insurance because the necessarily high interest rates charged in the contract of bottomry ran afoul of the Catholic Church's prescriptions on usury.

${ }^{4}$ As Robert Hunter wryly comments on the Florida hurricane insurance market, "In a locale whose major university football team is called the Hurricanes, the question is not whether a hurricane will strike but when and how big. Hunter [1994], p. 476.
} 
reflecting the catastrophe (hurricane) element in this line. A pure hurricane line would show a similar pattern to the earthquake line. This pattern of loss ratio is also clear from earthquake data for the state of California in Table 2.

The fundamental problem of catastrophe insurance thus seems clear: how to smooth large losses over time. Unlike every other line of insurance, the contract of catastrophe insurance, as presently structured, requires that the seller have access to a large pool of liquid capital in every year in which the contract stands. ${ }^{5}$ In principle, the insurance company would require enough capital to cover the largest possible catastrophe loss that might occur. For example, for an event with a 1 percent annual probability, the expected loss (or the annual premium) would approximately equal $1 \%$ of the required capital. Put the other way, the required capital would approximately equal one hundred times the expected annual loss. Since such large pools of capital do not exist, firms have withdrawn from this market rather than bear the risk of insolvency.

There are many possible mechanisms for providing the necessary intertemporal diversification, including government intertemporal tax-transfer policies, capital market solutions, and insurance industry structures. In this paper, our primary focus is to describe the major solutions that are available existing insurance industry structures. ${ }^{6}$

Before turning to external sources of capital, we begin in Section 4 by considering the factors which limit the quantity of capital the companies can hold internally.

\section{What Limits Insurance Company Capital Held for Catastrophes}

There are several institutional features of the modern contract of insurance which work against the accumulation of capital from which to pay future catastrophe losses. We discuss each in turn. a) Accounting Requirements

As is well known, accounting practices in property/casualty insurance preclude an insurance corporation from earmarking capital surplus to pay for a future catastrophe loss (i.e. one that has not yet occurred), even though the occurrence of that loss at some time is highly likely, see e.g. Mooney and Cohen [1991]. ${ }^{7}$ The relevant provision is FASB Statement No. 5 Accounting for Contingencies. Moreover, even creative efforts to smooth loss ratios by multiple year

\footnotetext{
5 This point has been made by Sean Mooney who compares the geographical diversification provided by say fire insurance with the intertemporal diversification required by catastrophe insurance, Mooney [1995].

${ }^{6}$ As a referee has suggested, it would be interesting to provide an assessment of the efficiency or Pareto Optimality of each approach for different layers of catastrophic risk. Our goal in this paper, however, is the more limited one of identifying the issues associated with these approaches.

${ }^{7}$ Some insurance corporations clearly recognize that this accounting rule has undesirable features for a corporation's annual reports. Thus Zenith National Insurance Corp. Annual Report, 1994 p 27, "Property Insurance exposes Zenith to the risk of significant loss in the event of major adverse natural phenomena known in the industry as a catastrophe. These catastrophes may cause significant contemporaneous financial statement losses, since catastrophe losses may not be accrued in advance of the event."
} 
retrospectively rated reinsurance contracts (RRC's) have run afoul of US regulators' concerns with reserve accounting, see Wallace and Althoff [1994]. The view implicit in these accounting rules is that the insurance company's reporting will more realistically reflect its true financial situation when catastrophe income and losses are accounted for one year at a time, rather than over a longer term with earmarked capital accumulated in good years being used to smooth out losses in future bad years..

Of course nothing prevents an insurance company from allocating retained earnings to a capital surplus account (subject to regulatory approval), but there is no way that the corporation can irrevocably earmark this surplus towards payment of a catastrophe risk. In principle, all of the unassigned surplus is available to pay such losses, but this surplus is also available for other purposes such as premium growth. ${ }^{8}$

It is instructive to examine this issue in the light of the work of the recent Florida Academic Task Force on Hurricane Catastrophe Insurance (Collins Center for Public Policy [1995]. This task force surveyed insurance companies on the question of the size of the insurance surplus available to meet hurricane losses in the State of Florida, both with respect to their own capacity and with respect to the capacity of the industry as a whole. Among the responses were:

\section{$\underline{\text { State Farm Insurance - Vincent J. Rio III, Counsel }}$}

State Farm does not have a definitive number for the maximum capacity of the private insurance industry. State Farm can dedicate approximately $\$ 1$ billion in retention plus their co-pay in excess of the retention for claims associated with a Florida hurricane catastrophe.

\section{Allstate Insurance Company - David G. Nadig, Counsel}

The total capacity for the private insurance industry and the CAT (Florida Catastrophe Fund) fund to pay claims for a Florida hurricane without impairment is $\$ 14$ billion ( $\$ 10$ billion and $\$ 4$ billion, respectively). Allstate can dedicate $\$ 1$ billion of its capital and surplus to pay claims for a Florida Hurricane catastrophe.

It would be a very interesting follow up question to these corporations to ask what process was used to come up with these numbers. For example, these answers might be contrasted with the answer given by the Westfield Companies.

\footnotetext{
${ }^{8}$ For example, following the losses created by hurricane Andrew, a major insurance company reallocated some surplus funds from its auto insurance subsidiary to its property insurance subsidiary.
} 


\section{$\underline{\text { Westfield Companies - Jack Adornetto, Senior Vice President }}$}

The Westfield Companies do not have an answer as to the maximum capacity of the private insurance industry, but they do suggest that the results of hurricane Andrew be used as a gauge. Additionally, the Westfield Companies do not allocate capital and surplus by states or territories, therefore an amount as to how much they can allocate to pay claims for a Florida hurricane catastrophe can not be provided.

Obviously, whatever principles govern U.S. accounting rules with regard to property casualty insurance, they do not include providing policyholders with a clear picture of the funds available from their insurance company to meet their catastrophe losses.

\section{b) Tax Provisions}

Even if accounting principles were to allow the companies to accumulate capital that was earmarked for catastrophes, the companies' only tax incentives to do so are the tax loss carry forward and backward tax code provisions. ${ }^{9}$. In particular, under current federal tax law, the retained earnings would be taxed as corporate income in the year in which they were set aside, and the interest income on these reserves would also be taxed. In this sense, the tax code offers insurance companies no incentive to earmark funds 'for a rainy day,' see Wallace and Althoff [1994].

On the other hand, it could be argued that monies set aside to meet inevitable claims are a business expense, and therefore such monies and the interest on such monies should be granted tax free status. Of course, it would be important to require that these funds only be available to meet future catastrophe losses, for otherwise the companies could use the funds to cross subsidize other lines of business. This is exactly the situation in many European countries, where it seems to work quite fine.

\section{c) Cash Surplus, Myopic Behavior, and Takeovers}

The accumulation of capital to pay for future catastrophe losses is also limited by the risk that the managers of publicly traded companies face from unfriendly takeovers. These takeovers may reflect either the agency-cost aspects of surplus cash or the myopic behavior of stock market investors.

It is instructive to consider the case of the Chrysler Corporation. This company tried to self insure against a "catastrophe", the down turn in the business cycle and its effect on Chrysler's revenues, by accumulating a large stock of cash (over $\$ 7$ billion). This stock of cash, however, attracted the attention of a corporate raider (Mr. Kirk Kerkorian) who had no real complaints about the quality of Chrysler's management of the automobile business, but who felt he had much better uses for Chrysler's "catastrophe" reserve of cash. ${ }^{10}$

\footnotetext{
${ }^{9}$ Furthermore, these tax loss provisions have no value if the company becomes bankrupt as a consequence of a catastrophic loss exceeds the financial resources the company has available.

${ }^{10}$ For a discussion of the role of free cash in generating takeover bids, see Jensen [1986].
} 
The agency-cost aspects of carrying a large hoard of free cash are confirmed in the study by Blanchard, Lopez-de-Silanes, and Schleifer [1994]. This study of firms which received cash windfalls but had no internal investment opportunities found that "firms that hold the cash and do not waste it are themselves acquired within a few years. This finding suggests that the only equilibrium strategy for a managerial firm is to waste the cash, for otherwise another managerial firm will buy it and waste the cash itself." p. 359.

It is far from clear why cash within a firm is "underpriced", but this seems a fact of life. Of course, liquid assets earmarked for future catastrophe losses are not 'free cash' for a company with a long-term horizon, but there is nothing in the rules of the corporate game to prevent a shorthorizon raider from buying a cash rich insurance company, taking its cash reserve, and closing shop. Also, if this insurance company is a wholly owned subsidiary of another company, there is nothing in law to prevent the parent company from treating the surplus of its insurance offspring as a convenient source of cash. Indeed, given that a catastrophe does not occur in a given year, the surplus could be allocated to any corporate purpose, including shareholder dividends.

The problems which publicly traded companies can face in taking the long-run view have recently been discussed by Jeremy Stein [1988], [1989]. As he shows, managers may reduce their company's reported earnings in the short-run when they undertake policies that maximize the firm's long-term value. This may give well-informed traders the opportunity to take over the company at a low price, reflecting the low short-run earnings. This mechanism reinforces the takeover risk for an insurance company holding liquid assets.

The legal benefits bestowed by limited liability make this problem worse. With limited liability, an unscrupulous corporation could simply distribute catastrophe premiums as dividends if there is no loss, then declare insolvency if a catastrophe hits. The recent declaration of bankruptcy by Dow Corning in the face of liability claims arising from breast implants provides obvious parallels. All of which is to say that the incentive structures associated with the publicly traded limited liability corporate form are not conducive to the sound provision of catastrophe insurance.

\section{d) The Mutual Form}

Of course joint stock limited liability corporations are not the only legal entities which offer insurance. One notable feature of the U.S. insurance market is the co-existence of the for-profit stock companies and non-profit mutual companies. In 1991, for example, 58.6\% of the market for homeowner's multiple peril was provided by companies organized as mutuals, see Born, Gentry, Viscusi, and Zeckhauser [1995].

The problem of protecting cash assets is less severe under the mutual form. As noted by Mayers and Smith [1981], mutuals have the disadvantage that the absence of a market for stock increases the costs of taking over the firm in order to oust ma nagement which is not acting in the owners' interest. 
In the context of the cash asset problem, however, this same increased cost of takeover actually works to the advantage of the mutual form. By virtue of these higher takeover costs, managers in mutuals are more able to accumulate cash assets without having to worry about raiders. Indeed, in a study of 30 insurance companies which changed ownership form from stock to mutual, 8 companies changed form precisely to prevent loss of control to outside investors, Mayers and Smith [1986]. As Fletcher [1966] notes in her original study of the motivations underlying these mutualisations, 7 of these 8 mutualisations were made to prevent substantial surpluses from passing to speculative interests.

That mutuals have accumulated larger cash assets than stock firms behind the protection of the mutual form is confirmed in the study by Wells et al [1995]. They report that in their sample of 1295 life and health insurers, mean free cash of the mutuals significantly exceeded that of the stock firms, controlling for size, regulatory environment, and risk.

Why then is catastrophe insurance not provided by private companies organized as mutuals? There are some suggestive answers to this question. In states in which insurance rates are regulated (e.g. California), large cash reserves could cause a mutual to run afoul of the regulatory process. Or, consumer activists, seeing a large holding of cash, might argue that this is a good reason to roll back rates. Moreover, even in the absence of regulation, policyholders may, and do, sue the directors of mutual firms to force the distribution of reserves.

In the long run, this question is probably moot. In many states, the process of demutualisation is now being made much simpler, Hemmings and Seiler [1995]. Thus in the future any mutual which accumulates a large cash reserve could be demutualised just as mutual savings and loans were demutualised in the 1980's. This threat largely removes the reserve protection of the mutual form, making it de facto just as dangerous for the management of mutuals to acquire large cash surpluses as it is for the management of stocks. All of this suggests that both stocks and mutuals will have difficulty accumulating an ex ante surplus to meet a large anticipated loss under present institutional arrangements.

\section{e) Regulatory Constraints}

Insurance is a highly regulated industry. The form of regulation represents a compromise among the interests of the companies, homeowners, and consumer activists (see Kleindorfer and Kunreuther [1996]). Because there is scientific disagreement about the probabilities of various catastrophes, a given quantity of accumulated capital which might appear conservative to an insurance company, may well appear excessive to a regulator responsive to consumer activists. These activists may use the level of surplus capital as an argument that the premium level is too high. This may make the insurance companies reluctant to raise their premiums to the level necessary to accumulate adequate capital on the grounds that this increase may seem 'unfair'. The same issues of fairness arise in the pricing of auto insurance and are discussed in Jaffee and Russell [1995]. Even if premium ceilings are not currently enforced by regulators, the companies may still wish to withdraw from the market, for fear that the ceilings will be enforced at a later date and it will then be difficult to leave the market. ${ }^{11}$

\footnotetext{
11 This point was made to us by Martin Feldstein of the National Bureau of Economic Research.
} 
The conflicts can be further illustrated by looking at the strategies insurance companies actually follow when they set catastrophe line premiums. In particular, it is interesting to examine why insurance companies typically raise rates substantially following a catastrophe. For example, following Hurricane Andrew in the Miami area, average rates have increased 65\% between 1992 and 1995. Following the Northridge earthquake, 101 insurance agencies requested rate increases ranging from $17.30 \%$ (Calfarm) to $585 \%$ (American Reliable). State Farm, for example, requested a $97.2 \%$ increase and was granted a $65 \%$ increase.

This question is clearly of interest to Commissioners in prior approval states. How should they deal with such a premium rate increase request? Based on our prior discussion, it seems that a Commissioner cannot dispose of this request until the insurance company answers two related questions.

1. What dynamic premium strategy were you using before the catastrophe?

2. What new information relevant to this strategy is provided by the occurrence of the catastrophe?

Unless it is known how the occurrence of the catastrophe affects the company's dynamic premium strategy, it is difficult to see how a rate increase request can be discussed on a rational basis. We will illustrate this with an earthquake insurance example.

Suppose this information is provided. If the dynamic premium strategy already reflects full information regarding an earthquake's likelihood and cost, there can be no justification for a rate increase just because the event has happened. By analogy, stock prices do not fall when a corporation's earnings fall, if the fall in earnings was already anticipated in the company's stock price. A rate increase also cannot be justified simply on the grounds that the size of the earthquake loss was large. For example, suppose population shifts in the 1980's increased the risk exposure in the Northridge area. This fact must have been known to insurers before the earthquake took place and should be already reflected in any rational dynamic premium strategy.

A rate change may be justified if the occurrence of a major earthquake can be shown to provide new information regarding the shape of the insurer's loss distribution. For example, the Northridge earthquake revealed that some forms of office construction were less able to withstand an earthquake than previously thought. This would be the basis for charging higher premiums in the future.

New information could also lead to rate reductions. For example, if the findings of the engineers following the Northridge earthquake lead to building code changes which over the long run make the average building more likely to withstand a major earthquake, the average loss exposure is actually reduced by an event which reveals unexpected structural weakness. This would require a reduction in the level of premiums.

\section{The Role of Capital Markets}


Given the problems for insurance companies in accumulating retained earnings to pay for future catastrophe losses, it is useful to consider whether capital market instruments can help solve the fundamental problem of the mismatch between the size of annual premiums and the much larger size of possible catastrophe losses. Since premium cash flow must eventually cover all losses, it is useful to consider how premiums are actually set.

\section{a) Premium Setting for Catastrophes}

The science of catastrophe prediction is not well developed, in the sense that the size, frequency, and location of recent major hurricanes and earthquakes have surprised most experts. Meteorologists, for example, are now debating whether the increased frequency of hurricanes in the 1990s compared to earlier decades is an exception or a return to a more normal frequency. Similarly, the last two California earthquakes occurred on fault lines that were not even known to seismologists prior to the events.

For the sake of discussion, however, suppose we assume that it is certain that a $\$ 30$ billion earthquake will hit California in the next 30 years, and suppose we consider an insurance company with $10 \%$ of the market, i.e. a company facing a $\$ 3$ billion loss. What premium strategy ought this company to pursue?

Because of the absence of stability in loss experience, any premium policy based on averaging recent losses clearly will not work. A more viable strategy would be to divide the $\$ 3$ billion into equal annual premiums of $\$ 100$ million. (For simplicity we ignore time value of money issues). If these premiums can be unambiguously set aside in a fund, perhaps being placed in a trust subsidiary, ${ }^{12}$ it will eventually provide coverage against the $\$ 3$ billion loss.

It is clear that this arrangement provides no help if the $\$ 3$ billion loss should occur in the first year of operation. (Think of the example of the 20th Century Insurance Company which had the misfortune to enter the earthquake market in the year of the Northridge earthquake). If there is no access to capital markets, there is simply no way that an insurance company can accumulate premiums fast enough to guarantee that it will have sufficient surplus to meet a catastrophic loss. We therefore now consider capital market solutions to this problem.

\section{b) The Role of Capital Markets in Adjusting Losses to Premiums}

We have just seen that the 'early hit' problem rules out the payment of losses out of premiums in the early years of a catastrophe insurance line. To guarantee payment of losses, therefore, it is essential that the contract of catastrophe insurance be linked in some way to the market for capital. Capital market instruments, of course, cannot reduce the real expected losses due to catastrophes-only pre-disaster mitigation can do that. However, capital market instruments can enhance the degree of intertemporal diversification, thus reducing the risk loading component of insurance premiums and thereby creating a more efficient market.

\footnotetext{
${ }^{12}$ A wholly owned subsidiary would be in effect a 'captive' of the insurance company, performing the same selfinsurance function that captives perform for their parent companies. Similar tax issues would then arise.
} 
A variety of capital market instruments have been introduced to enhance the operation of catastrophe insurance markets. Some of these instruments allow the insurance company to transfer the risk directly (such as reinsurance), whereas with other instruments the insurance company retains the ultimate risk, but is able to create a more convenient intertemporal flow of funds (as with lines of credit). Many instruments provide a hybrid of risk transfer and intertemporal transfer. We now describe some of the more important instruments, including a new source of potential capital.

\section{Reinsurance}

The contract of reinsurance is the traditional means by which an insurance company reduces the size of its potential losses. For the insurance industry overall, reinsurance provides an important mechanism for achieving the benefits of geographic diversification. On the other hand, adverse selection limits the ability of the reinsurance market to function efficiently and the industry's capital capacity sharply limits the amount of risk that can be covered (Cutler and Zeckhauser [1996]).

Although catastrophe reinsurance capacity has recently grown sharply, international reinsurance catastrophe capacity is still only about $\$ 15$ billion. ${ }^{13}$ Furthermore, an individual primary insurance company is unlikely to obtain more than perhaps $\$ 400$ million in catastrophe reinsurance. These amounts appear small compared to the possibility of an aggregate $\$ 100$ billion earthquake loss or a $\$ 10$ billion loss for a large company such as State Farm. Even putting aside the question of reinsurance capacity, however, the contract of reinsurance is not a magic potion by which we solve the problem of giving incentives to publicly traded limited liability companies to set aside large amounts of liquid assets to pay for future catastrophe losses

In the contract of reinsurance, total annual premiums $\mathrm{P}$ and total losses $\mathrm{L}$ are split up and held by the direct insurer and the reinsurer according to some sharing rule. The repackaging of $\mathrm{P}$ and $\mathrm{L}$ can be shown to be in general beneficial to both the primary insurer and the reinsurer, but it cannot avoid the arithmetic fact that when the contracts of insurance and reinsurance are considered together, the ratio of losses to premiums, $\mathrm{L} / \mathrm{P}$, in any one year is what it was before the reinsurance and is, in the case of catastrophes, potentially high.

Reinsurance does not of itself solve the problem of providing capital to meet such a case, though by repackaging the risk in a more attractive form, it may induce more capital into this line. However, when this capital is provided by limited liability joint stock companies, all the problems discussed above are just pushed back one stage into the laps of the reinsurers. If rates in this market fall, there is nothing to prevent a reinsurer from taking the surplus and exiting.

At Lloyds, unlimited liability and a three year 'open book' accounting period prevented this capital flight, but, after 300 years, Lloyds has now instituted limited liability for some of its

13 Mooney [1995] and Cutler and Zeckhauser [1996] both discuss the reinsurance industry data available from A.M. Best. 
risks. ${ }^{14}$ This experience illustrates the difficulty of obtaining committed capital, and shows that without such capital the reinsurance market is just as open to problems of financial solvency as the primary market.

\section{Act of God Bonds}

Recognizing that committed capital is one of the keys to viability, a number of investment banks have developed bond instruments which provide capital to an insurance company in advance of a catastrophe. Since these instruments will only be exercised in the event of a catastrophe they are known as Act of God bonds.

For example, Nationwide Mutual Insurance Company, in a deal arranged with J. P. Morgan and Salomon Brothers, created a trust subsidiary which issued $\$ 400$ million worth of bonds, with the proceeds placed in Treasury Bonds which were used as collateral for the issue. In the event of a catastrophe, Nationwide could liquidate the Treasury Bonds in order to pay policy claims, but would still retain the obligation to pay off the bonds. This is thus the case of an intertemporal transfer without a risk transfer. In another example, Guy Carpenter and Company, a unit of Marsh and McLennan, offered bonds that pay interest at $10 \%$ above Treasury rates; were the defined catastrophic event to occur, Marsh and McLennan's obligation to make interest and principal payment is ended. This case thus combines an intertemporal transfer with a risk transfer.

Although both of these arrangements are treated as financial innovations, they are nothing more than modern versions of the Roman contract of bottomry discussed earlier as one of the capital arrangements which makes private catastrophe insurance viable. If this modern version of bottomry is to expand, it is essential that the bonds be priced correctly. Because payments are uncorrelated with the market, modern portfolio theory would suggest that the risk premium necessary to induce investors to hold a small fraction of their portfolio in such assets is small. ${ }^{15}$ Under the assumptions of the capital asset pricing model, this would make the required rate of return on these bonds approximately equal to the return on Treasuries. To generate this required rate of return, the posted interest rate would have to be high enough to offset the expected loss of principal due to a catastrophic event.

On the other hand, portfolio managers may be reluctant to hold these assets either because they believe modern portfolio theory does not apply to an asset with such a skewed return distribution, or because of purely behavioral concerns with the nature of this instrument. If these pricing issues can be resolved, however, Act of God bonds and their like would seem to be an important potential source of new capital to the line.

\footnotetext{
14 This change to limited liability followed lawsuits in which some syndicates (mostly investors new to Lloyds) accused their broker of accepting known bad risks from other syndicates (mostly 'old money') whom these same brokers also represented.

15 Since catastrophe insurance market failure is frequently viewed as a problem of size, recall that the value of traded stocks in the US alone is over $\$ 5$ trillion so that a $\$ 50$ billion catastrophe loss is only $1 \%$ of this market, a common daily change in aggregate market indexes.
} 
It is also worth noting that the interest rate on these bonds will be a business expense to an insurance company. If this interest rate rises, this provides a justification for a premium increase in prior approval states. More generally, the more an insurance company uses the capital market, the less it needs to follow a dynamic premium strategy and the easier it is to determine whether or not a rate increase is justified. This is one of the benefits of separating out the capital and risk aspects of catastrophe insurance.

\section{Catastrophe Futures and Options}

The Chicago Board of Trade introduced catastrophe futures and options on December 11,1992. ${ }^{16}$ These contracts have been very lightly traded, and in response to this, the C.B.O.T. on September 29, 1995 introduced 9 new catastrophe options, 1 National, 5 Regional, and 3 State (Florida, Texas, California).

For our purpose, the primary questions raised by these new markets are:

a) Will option markets lead to significant injections of new capital into catastrophe insurance?

b) Are these contracts structured so that performance is guaranteed in the event of a large loss?

Certainly the experience to date is not encouraging. The basic problem seems to be finding takers on the risk-bearing supply side of the contracts. Apparently there is no obvious reason to use these contracts as a hedge against an earthquake not occurring, so the normal source of supply from hedgers and arbitrage traders is not available. This leaves only speculative capital as a source of risk-bearing supply.

If option contracts are to be successful, it seems clear that they must attract more than purely speculative capital. In addition, it would seem to be necessary that the pricing of these contracts be reasonably understandable. It may be argued that one of the major reasons for the success of stock and interest rate option contracts was the simultaneous development of the Black/Scholes option pricing model, Black and Scholes [1973], which allowed market participants to detect 'under' and 'over' priced options and trade accordingly.

At the present time no such tool exists for pricing catastrophe options. The Black/Scholes pricing argument is based on the fact that in a small amount of time the movement in the price of the asset on which the option is written (the primary asset) is such that this price movement can be completely hedged with one other asset, the option itself (the derivative asset). ${ }^{17}$

The dynamics of catastrophe losses (these losses being the primary asset in the catastrophe options market) differ completely from the dynamics of stock prices. Catastrophe losses have

\footnotetext{
${ }^{16}$ For a discussion of these contracts see Hoyt and Williams (1995)

${ }^{17}$ Technically, in a small amount of time the primary asset has a return distribution with only two moments, a mean and a variance. The derivative asset, therefore, also has two moments, a mean and variance and is uncorrelated with the primary asset. This allows the possibility of a hedge, see e.g. Russell [1988].
} 
sample paths which are usually zero but which are sometimes very large. This creates a jump process with a very skewed distribution, even in a short period of time, so this risk cannot be fully hedged with only 2 assets. It would seem that a new and potentially far more complex option pricing theory needs to be developed for catastrophe options, and until this theory is established it is unlikely that trading capital will flow into this market in any sizable amount.

The second question which arises relates to the ability of the C.B.O.T. to ensure performance on this contract in the event of a large catastrophe loss. Insufficient guarantee of contract performance in the event of a large loss was listed as a major reason for not using this market in a survey of insurance firms, D'arcy and France [1992].

Contract performance issues are dealt with by the C.B.O.T. through a clearing house (the Board of Trade Clearing Corporation, B.O.T.C.C.) which is a separate entity from the C.B.O.T. This clearing house has three instruments with which to try to ensure financial solvency:

a) Performance bond margins;

b) Marking to market;

c) A fund of capital and committed credit.

We examine each of these in turn.

\section{Performance Bond Margins}

The C.B.O.T. requires its members to deposit performance bonds in the form of liquid capital. The size of this performance margin is based on the contract's volatility and the net position of the firm and its customers. Typically the size of these margins is determined by a system called S.P.A.N. (Standard Portfolio Analysis of Risk). The principle underlying S.P.A.N. is that market participants should deposit sufficient margin to "cover the one day loss their portfolio might reasonably incur.' PCS Options, A Users Guide C.B.O.T. [1995].

The C.B.O.T., however, recognizing the special capital needs of catastrophe options, applies S.P.A.N. only to the purchase of calls and the purchase and writing of puts on this contract. A separate special margin is required for the writing of naked (uncovered) calls. To be able to write a naked call, the investor must deposit $20 \%$ of the difference between the strike price and the maximum possible loss. The C.B.O.T. offers two types of option contracts, a 'small cap' contract with a maximum index value of 200, and a 'large cap' contract with a maximum index value of 500. Each point of the index corresponds to a reported loss of $\$ 100$ million, so the small cap contact hits its maximum value when there is catastrophe with losses equal to or in excess of $\$ 20$ billion.

Consider, as an example, an investor who writes 100 naked calls on the small cap contract (maximum value $=200$ ) at a strike price of 10 . This investor would be required to post a margin of $\$ 760,000$ calculated as follows: 100 (number of contracts) x 190 (maximum loss-strike price) x $\$ 200$ (dollar value of an index point) x 0.20 (margin percent). 
On the other hand, if a $\$ 20$ billion catastrophe occurs, the writer of this call option must deliver $\$ 3,800,000$. In this case, the margin is inadequate in the amount of $\$ 3,040,000$. Clearly this raises legitimate questions about the adequacy of the $20 \%$ rule, and to some extent the C.B.O.T. has recognized this by requiring that traders who write more than 25 naked calls have their names and circumstances reported to the Board. ${ }^{18}$

It is also noteworthy that such option contracts provide no additional reinsurance value for aggregate losses that exceed $\$ 20$ billion. For example, the holder of an option contract receives the same payout for an aggregate catastrophic loss of $\$ 20$ billion as for one of $\$ 50$ billion.

\section{Marking to Market}

For any asset where price movement in a small amount of time is not large, marking to market provides early warning of potential financial difficulties before these difficulties become overwhelming. Indeed the C.B.O.T. states "The single most distinguishing feature of futures and options markets - and the most vital procedure for maintaining the financial integrity of the markets - is the daily settlement of gains and losses. The B.O.T.C.C. marks all open positions to market twice daily" C.B.O.T. [1995].

Again, however, we note that a catastrophe option is not written on an asset with typical time series properties for its price. The daily movements in the California Catastrophe Option, for example, are likely to be close to zero, reflecting the infrequency of earthquakes. On the day of an earthquake, however, the price will take a large jump. Marking to market provides little advance warning of financial difficulty in this case.

\section{The Capital Position of the B.O.T.C.C.}

In the event that an investor does not meet his obligations, the legal obligation to meet a margin call lies on the C.B.O.T. clearing firm which made the trade. If this firm cannot find the necessary capital, the B.O.T.C.C. takes over the liability for performance. The B.O.T.C.C. has total capital of $\$ 140$ million and further committed credit of $\$ 300$ million. This total sum, $\$ 440$ million, would seem to be rather small, given the huge potential losses in this market.

All in all, it seems fair to say that, although catastrophe options and futures are an innovative way of trying to attract capital to the catastrophe insurance line, their prospects for success seem dim. Moreover, the value of the primary asset underlying this derivative, (the size of the catastrophe loss) has such a different pattern of stochastic price movement from the price pattern of all other primary assets whose derivatives are traded on the C.B.O.T., it is clear that special attention must be given to the question of the capital adequacy of those who write calls in this market. The C.B.O.T. clearly recognizes this, but legitimate questions remain whether, any more than the reinsurance market, the futures/options markets solve the problem of having sufficient capital on hand if the 'big one' hits.

\section{Mortgage Lenders: An Alternative Source of Capital}

18 This section is based on telephone discussion with Mr. Bruce Domash, Margin Division C.B.O.T. 
In a catastrophe, the major source of loss is damage to residential and commercial property. For example, in the Northridge earthquake, of the $\$ 12.5$ billion in insured loss, $\$ 6.5$ billion was damage to residential property alone (California Department of Insurance estimate). This suggests that the mortgage lending industry could be a sensible source of capital for funding the reconstruction following a catastrophe.

In fact, mortgage lenders are already at risk when a catastrophe occurs, since mortgage default rates will rise when there are large uninsured losses on mortgaged structures. The actual default rates from catastrophes have been low so far in part because the lenders have responded to potential defaults by renegotiating the loan terms following the catastrophe (so-called forbearance) or by extending additional loans for reconstruction on a preferred basis. Loan and insurance pricing would be more rational, however, if the lenders anticipated these consequences of a catastrophe by providing some form of catastrophe insurance on an ex ante basis. This could be interpreted as a return to the older contract of property 'bottomry,' in which the lender bears the catastrophic risk, pricing this risk as a component of the loan interest rate.

There are many possible contractual arrangements through which lenders could provide catastrophe insurance. For example, the lender could simply provide traditional insurance, making cash payments for losses incurred. In this case, a lender would face the same liquidity needs that we described above for an insurance company, although the banking institution has an obvious advantage over an insurance company in providing this liquidity. Alternatively, the lender could agree to advance the amounts necessary for reconstruction, but add the advanced amount to the mortgage debt of the property owner. In this case, the financial loss remains with the property owner, but the funds to reconstruct the property are provided automatically, and the cash flow realization of the loss occurs only over time as the property owner makes payments on the now larger mortgage.

Of course, the details of such a scheme require further analysis. In particular, the GlassSteagall Act that prohibits banking institutions from selling insurance would probably have to be modified. The removal of this constraint on banking powers is being debated currently in Congress, and the issue of catastrophe insurance provides a new factor in this debate.

\section{The Role of Government in Providing Catastrophe Insurance}

Our discussion has identified 4 factors that have curtailed the ability of private markets to provide catastrophe insurance:

1) Accounting rules prohibit the assignment of accumulated surplus as irreversibly dedicated reserves against possible future losses. FASB has resisted changes in these rules.

2) Retained earnings are fully taxable, even when used to accumulate a capital surplus for possible future catastrophe losses. The IRS has resisted changes in these tax regulations; for example, it originally denied tax exemption for the California Earthquake Authority (see discussion below). 
3) The size of the market for reinsurance is limited, thus allowing insurance companies to hedge only a small amount of their risk. Although there have been important flows of new capital to these markets, the capacity is still small relative to the size of catastrophic risks.

4) Regulatory constraints prevent the setting of high enough premium levels due to perceptions of unfairness. In particular, consumers do not believe that catastrophic events necessarily provide new information that would warrant higher premiums.

The governments in three states which are at significant risk due to natural disasters-California (earthquakes), Florida (hurricanes), and Hawaii (hurricanes)--are in various stages of developing "plans" that address the catastrophe insurance issues. State intervention has been made more urgent because, following the large losses created by hurricane Andrew in Florida in 1992 and the Northridge earthquake in California in 1994, insurance companies in the two states stopped writing hurricane or earthquake insurance on a voluntary basis. Both states responded by activating involuntary underwriting associations, originally created as assigned risk pools for special risks (as in auto insurance) to provide stopgap coverage. The Federal government also already plays a role in catastrophe relief through the Federal Emergency Management Administration (FEMA), the national Flood Insurance Program, and special congressional appropriations for disaster relief, and there are proposals for a national catastrophe insurance fund.

In this section, we summarize and evaluate the various programs and plans ${ }^{19}$. In particular, it is interesting to see how the governmental plans deal with the four problems just described. We begin with the involuntary underwriting associations activated in California and Florida as stopgap measures.

19 Information on the plans is taken from Collins Center for Public Policy [1995], Appendix A. 


\section{a) Involuntary Underwriting Associations}

Florida has two involuntary underwriting associations, The Windstorm Joint Underwriting Association (WJUA) created by the Florida legislature in 1970 and the Florida Residential Property and Casualty Joint Underwriting Association (FRPCJUA) created as part of the hurricane Andrew legislative package in 1992. All licensed property insurers must participate in the Associations which are governed by Boards elected by the companies and are regulated by Florida Department of Insurance. The Associations function as insurance companies, collecting premiums, purchasing reinsurance, and paying claims. Were either Association to become insolvent, the participating companies would face assessments, based on each company's market share (to a maximum annual percentage of each company's gross premiums), until the deficit was eliminated. Following hurricane Andrew, coverage provided by the Associations has grown dramatically, reaching close to $\$ 100$ billion of coverage on almost 1 million policies in 1995, making them the third largest homeowner and hurricane insurance providers in the state (after State Farm and Allstate).

In California, following the Northridge earthquake, the Commissioner of Insurance broadened the coverage provided by the Fair Plan, originally created to provide residual business coverage following the Watts riots, to include homeowners and earthquake policies. The Fair Plan operates as an involuntary joint underwriting association, in much the same manner as the Florida associations. It is now the primary source of new homeowners earthquake coverage in the state, although its policy limits are very low, and many homeowners "wrap" additional private market homeowners coverage around the Fair Plan policy.

The involuntary underwriting associations in Florida and California have several features that make them untenable as long-run solutions to the provision of catastrophe insurance. First and foremost, the associations are involuntary, and are not considered a viable long-term solution by the major participating companies. Second, the associations provide the existing companies an incentive to reduce their market share and provide possible new entrants an incentive not to enter at all. Third, the associations dampen the normal private market incentives to set premiums and make claim payments efficiently. Fourth, there are legal and financial questions concerning the speed and actual payment of assessments by the companies.

\section{b) Integrated State Plans}

The states of California, Florida, and Hawaii each have, or are in the process of creating, public entities (an "authority" in California and a "fund" in Florida and Hawaii) to provide the primary catastrophe coverage for the state. In broad terms, each of the plans deals with the private market problems listed above as follows:

1) The accumulated capital is irrevocably earmarked to a catastrophe reserve fund and the return on capital is exempt from Federal taxation.

2) The liability of the private insurance companies would have a fixed upper limit, determined in the aggregate by the capitalized value of the plan and for each company by its paid-in capital in the plan. The maximum liability of the Plans is also reduced by setting standard policy coverage that is 
lower than the amount previously available in the private markets. Policyholders bear the residual risk of loss for disasters where the aggregate losses exceed the Plans' capital limits or where individual losses exceed individual policy limits. ${ }^{20}$

3) Each of the plans uses part of its revenue to purchase reinsurance, both in traditional markets and using the new capital market instruments described above.

4) The premium rates in each plan are set by a public board of directors, which may limit the protests of consumer activists.

Some of the unique features of each state plan are described in the following.

\section{Hawaii Hurricane Relief Fund (HHRF)}

The HHRF is already functioning and is designed to provide up to $\$ 1.7$ billion in hurricane coverage in the state. If losses exceed that level, payments for losses are prorated and the public accepts the residual risk. Payments in excess of accumulated capital (up to the $\$ 1.7$ billion limit) would be funded through assessments on existing casualty policies (up to 5\%) on all property and casualty premiums (including auto) and a $.01 \%$ surcharge on mortgages. Eligible properties covered by property insurance are entitled to hurricane coverage, up to $\$ 750,000$ per risk on residential properties and up to $\$ 500,000$ per risk on commercial properties, subject to a choice of deductibles in the range of 1 to $5 \%$.

\section{Florida Hurricane Catastrophe Fund (FHCF)}

An initial version of the FHCF is already functioning and serves primarily as a reinsurance program, with a claims -paying capacity of about $\$ 5.5$ billion in 1995 . Private market insurers are allowed to "pass-through" FHCF reinsurance premiums, assessments, and surcharges to their policyholders. Under current law, any unfunded losses remain the responsibility of the insurance companies. However, there are current proposals (see The Collins Center for Public Policy [1995]) to institute a "cap" of $\$ 20.5$ billion on total company exposure (which is approximately twice the payments made to homeowners from Hurricane Andrew).

\section{California Earthquake Authority (CEA)}

The CEA is in process of implementation, following enabling legislation passed in early 1996. The CEA will issue standardized earthquake policies on behalf of all participating insurance companies. The standardized policy, called the Mini Policy, provides more limited coverage than was previously available in the private market, with the primary constraints being (a) a $15 \%$ deductible, (b) coverage only for primary home (no other structures including swimming pools), and (c) limited coverage of contents. The CEA will receive initial capital from the participating companies and accumulate further reserves on the basis of written premiums. At full

${ }^{20}$ The respective states have no liability for payment of claims in excess of funds available, nor is a policyholder eligible for benefits from the state's Insurance Guaranty Association. 
capitalization, the CEA is structured to provide contingent capital of $\$ 10.5$ billion, approximately the level of losses in the Northridge quake and approximately twice the level of losses that the Northridge quake would have created under the more limited coverage provided in the new policies.

\section{Evaluation of the Three Integrated State Plans}

Each of the state plans provides two primary benefits that have not been available to the private companies acting individually or through joint underwriting associations:

(1) The Internal Revenue Service has agreed that capital within the plans can accumulate on a taxfree basis.

(2) The risk of each individual company is fixed by the aggregate capital limits of the plan and by the firm's participating share therein.

It may be noted that:

(1) The tax relief provided to the state plans could have been provided directly to the private insurance industry at the same cost to the US Treasury. Of course, it would be essential that the retained earnings that are accumulated on a tax-free basis could be used only to pay future catastrophe losses.

(2) The plans are not providing catastrophe insurance as that term is normally understood in the private sector. The plans, in fact, provide only a stop-loss insurance policy, the maximum payoff being capped by the total value of available capital. In this sense, the plans "solve" the problem of how to find sufficient capital to meet a catastrophe loss only by defining the problem away. Furthermore, since the plans do carry the imprimatur of the respective states, they raise the question of how many policy holder/voters will be aware of the stop loss features of the policy, and whether it will be politically feasible to deny them access to public funds if the plan becomes insolvent .

\section{c) Federal Government Plans and Solutions}

The Federal government currently provides a form of catastrophe insurance through its various disaster relief programs such as FEMA, small business loans, and special congressional appropriations. Although these programs may be considered highly desirable from a humanitarian perspective, they are far from ideal from the viewpoint of risk management. First, since the recipients pay no premiums for the anticipated "coverage", the programs provide a federally subsidized incentive to take on risk (by building homes in high-risk areas). Second, government agencies undertaking "claims settlement" in the context of disaster relief are unlikely to verify the validity of "claims" with the efficiency of a private company, leading to fraud and waste.

Proposals have also been offered for the Federal government to organize catastrophe insurance on a national basis. These proposals often make appeal to the potential for national risk-sharing across different types of catastrophe risks. Of course, in principle, the existing reinsurance 
markets should be providing the same risk-sharing facility, which raises the question of what special features the government brings to this activity. A cynical, but perhaps realistic answer, is that it is hoped that national insurance would be subsidized insurance. Such subsidies, of course, are resisted by the residents in states that do not face any of the covered catastrophes, which is perhaps why legislation on federal catastrophe insurance has so far proven difficult to enact.

\section{d) Catastrophe Insurance in Other Countries ${ }^{21}$}

The United States is, of course, not unique in facing natural catastrophes. Hurricanes, earthquakes, or flooding occur in almost all countries in the world. This raises the question of how catastrophe insurance is provided in these countries.

The answer is that the government bears the risk in most developed countries in the world. New Zealand, for example, has had a government plan since 1944 to cover earthquakes and other "uninsurable risks". The program has remained solvent, while making payments on a number of disasters the country has suffered in recent years. However, the plan could not withstand a major earthquake hitting Wellington, which might cost $\$ 2$ billion. It is also noteworthy that in 1990, the New Zealand government reallocated \$239 million in insurance reserves funds to other government uses, indicating that even a government agency is not immune from raids on its catastrophe reserve.

In a similar way, France and The Netherlands have government programs for flooding and Japan has a government program for earthquakes. In all these cases, the primary activity of the government is to provide a nearly complete reinsurance facility for the private companies that underwrite the primary coverage. The government reinsurance funds have proven adequate for the catastrophic events that have occurred, but in all cases there is concern that the losses created by a major catastrophe would exceed the available resources.

\section{Conclusions}

Catastrophes are extreme events. They are extreme in that they impose huge losses. (This is what affords them such media attention.) However, catastrophes are also extreme in that, by the grace of God, they are infrequent. Elementary arithmetic shows that an insurance industry which was able to take the long view could spread a large infrequent risk (say a 20-year, $\$ 50$ billion, event) over time with annual premiums no less affordable than auto insurance. Why then does this not happen?

In this paper we have examined the causes of the failure of the private market in catastrophe insurance and have examined the conditions which would have to be established to make a purely private market viable. We have seen that a private market in marine insurance, a market with many catastrophe-like features, was completely viable because it solved what we have shown to be the catastrophe market's fundamental problem, a mismatch between the size of annual premiums and the size of maximum annual losses. The marine insurance market solved this problem in one of two ways:

${ }^{21}$ The discussion in this section is based on material in Mooney [1995]. 
a) by advancing all of the capital at risk to the insured at the beginning of the policy, forgiving the loan if a loss occurred, or

b) by arranging access to a large pool of capital (the unlimited wealth of the Lloyds' Names) with which to pay losses after the event.

Current incentive structures associated with publicly traded limited liability corporations work against these solutions. In particular such firms have no incentive to accumulate a pool of liquid assets from annual premiums since this pool cannot be earmarked to meet catastrophe losses.

If a private catastrophe insurance market is to be viable, certain reforms must occur which will provide the catastrophe insurance companies with access to the necessary capital. Basically, there are three ways that the companies can gain this access: (1) by accumulating their own capital through retained earnings, (2) by using specially designed capital market instruments, and (3) by capital provided through government programs. Two specific reforms we recommend are: ${ }^{22}$

1. A way must be found to permit an insurance company to retain its premium income against expected catastrophe losses in such a way that these funds cannot be used for other purposes. Like Ulysses, insurance companies must be able to tie themselves to the mast to avoid the siren calls of large pools of cash. If the firm can do this, it becomes plausible to provide state and federal tax exemption for the retained funds. After all, if precedent establishes that governments are willing to give a tax concession to a private company that contributes to a state plan, why would these governments not give the same tax concession if that company placed the same funds in a private earmarked trust?

2. Capital markets have shown themselves willing to provide capital in advance of catastrophes when the price is right, 'Act of God' bonds being the modern version of bottomry. The breaking down of the barriers between banking and insurance will enable more such contracts to be developed. Much intellectual capital is being used at present to try to find other ways to link capital sources to the uses of capital required by catastrophe insurers. There seems no reason to believe that other clever contractual structures will not be found. In particular, the growth of a firm's retained earning and its use of capital market instruments can interact, since the retained earnings can be used as a security for borrowing.

Alternatively, if private markets cannot be made viable, then government plans must be considered. However, the current state government solutions to the problems of the private market do not really come to grips with the problem of capital adequacy. By and large, these plans are not adequately capitalized to bear the losses that would be created by a major catastrophe. It is, of course, an open question what would actually happen in the event of a major catastrophe. It is perhaps not unreasonable to expect that taxpayers may well be the ultimate source of funds if a major loss occurs.

22 In principle, a comparison of these alternatives would require a formal welfare analysis. We must leave this ambitious task, however, for future research. 
The rash of catastrophes in the last 10 years has made most private providers of catastrophe insurance reluctant to provide this line. With the reforms suggested above, however, and a consequent increased level of support from capital markets, there seems to be no reason why a purely private insurance / capital industry cannot provide a catastrophe insurance product which provides adequate insurance to all policyholders and a reasonable level of profit for all concerned. 
Table 1: Adjusted Loss Ratio as a Percent

\begin{tabular}{|c|c|c|c|c|}
\hline Line & 1991 & 1992 & 1993 & 1994 \\
\hline Earthquake & 12.9 & 9.7 & 2.9 & 852.2 \\
\hline Fire & 56.6 & 77.0 & 53 & 55.7 \\
\hline Allied & 63.3 & 119.5 & 81.9 & 69.7 \\
\hline Multiple Peril Crop & 124.2 & 125.0 & 167.6 & 89.5 \\
\hline Homeowners M.P. & 76.5 & 124.5 & 69.8 & 72 \\
\hline Commercial M.P. & 56.9 & 78.9 & 60.4 & 63.5 \\
\hline Non-liability & N.A. & 90.2 & 61.2 & 63.8 \\
\hline Liability & N.A. & 65.6 & 59.5 & 63 \\
\hline Inland Marine & 50.7 & 60.5 & 59.1 & 59.3 \\
\hline Workers' Compensation & 89.3 & 84.8 & 73.5 & 62.2 \\
\hline Medical Malpractice & 59.7 & 80.9 & 67.4 & 55.4 \\
\hline Other Liability & 65.6 & 72.7 & 70.5 & 69.5 \\
\hline Product Liability & 62.0 & 82.1 & 136.5 & 91.5 \\
\hline Private Passenger Auto Liability & 77.2 & 73.584 .7 & 73.4 & 71.7 \\
\hline No-fault & 87.5 & 72.1 & 89.5 & 82.3 \\
\hline Other Liability & 75.9 & & 71.3 & 70.4 \\
\hline Commercial Auto Liability & 69.2 & 66.4 & 65 & 66.1 \\
\hline No-fault & 59.4 & 68.5 & 80 & 61 \\
\hline Other Liability & 69.5 & 66.3 & 64.5 & 66.2 \\
\hline Private Passenger Auto Physical Damage & 56.8 & 56.8 & 57.8 & 62.1 \\
\hline Commercial Auto Physical Damage & 46.1 & 48.9 & 49.6 & 53.8 \\
\hline Farmowners M.P. & 71.9 & 63.1 & 72.1 & 66.8 \\
\hline Ocean marine & 80.3 & 68.1 & 60.6 & 58.9 \\
\hline Financial Guaranty & 1.3 & 26.8 & 6.4 & 26.1 \\
\hline Mortgage Guaranty & N.A. & 54.3 & 52.5 & 54.3 \\
\hline Aircraft & 100.8 & 92.9 & 62.5 & 88.4 \\
\hline Fidelity & 41.8 & 47.5 & 32.6 & 34.4 \\
\hline Surety & 22.3 & 30.1 & 22.9 & 33 \\
\hline Glass & 33.4 & 29.5 & 26.8 & 25.5 \\
\hline Burglary and Theft & 23.9 & 17.1 & 19.1 & 21.2 \\
\hline Boiler and Machinery & 54.3 & 66.1 & 48.1 & 56.1 \\
\hline Credit & 46.1 & 26.3 & 30.4 & 33.1 \\
\hline Group Accident and Health & 70.7 & 72.4 & 70 & 67.6 \\
\hline Other Accident and Health & 70.0 & 67.5 & 59.6 & 57.1 \\
\hline Miscellaneous & 73.0 & 79.8 & 79.3 & 76.2 \\
\hline U.S. Total & 69.6 & 76.5 & 67.3 & 68.8 \\
\hline
\end{tabular}

Source: Best's Review, Various Years 
Table 2: California Earthquake Loss Ratio

(Ratio of Losses Paid to Premiums Received, as Percent)

$\begin{array}{cc}1971 & 17.4 \\ 1972 & 0 \\ 1973 & 0.6 \\ 1974 & 3.4 \\ 1975 & 0 \\ 1976 & 0 \\ 1977 & 0.7 \\ 1978 & 1.5 \\ 1979 & 2.2 \\ 1980 & 9.2 \\ 1981 & 0.9 \\ 1982 & 0 \\ 1983 & 2.9 \\ 1984 & 5.0 \\ 1985 & 1.3 \\ 1986 & 9.3 \\ 1987 & 22.8 \\ 1988 & 11.5 \\ 1989 & 129.8 \\ 1990 & 47 \\ 1991 & 17.2 \\ 1992 & 12.8 \\ 1993 & 3.2 \\ 1994 & 2272.7\end{array}$

Sources: A. M. Best. California Department of Insurance. Insurance Information Institute 


\section{Bibliography}

Academic Task Force on Hurricane Catastrophe Insurance [1995] Collins Center for Public Policy mimeo.

Black S. and M. Scholes [1973] The Pricing of Options and Corporate Liabilities Journal of Political Economy 81 \#3, pp. 637-654.

Blanchard, O.J., F. Lopez-de-Silanes, and A. Schleifer [1994] What Do Firms Do with Cash

Windfalls? Journal of Financial Economics, vol. 36, pp. 337-360.

Borch, K.H. [1990], Economics of Insurance, North Holland Amsterdam, 1990.

Born, P., W.M. Gentry, W.K. Viscusi, and R.J. Zeckhauser [1995] Organizational Form and Insurance Company Performance: Stocks versus Mutuals NBER Working Paper 5249

Brockett, P.L. and R.C. Witt [1982] The Underwriting Risk and Return Paradox Revisited Journal of Risk and Insurance 49, pp. 621-632.

Chicago Board of Trade [1995] PCS Options. A Users Guide. Chicago.

Collins Center for Public Policy [1995], Final Report, Academic Task Force on Hurricane Catastrophe Insurance.

Cutler, D. and R. Zeckhauser, "Reinsurance for Catastrophes and Cataclysms," mimeo, 1996.

D’Arcy, S.P. and V.G. France [1992] Catastrophe Futures: A Better-Hedge for Insurers Journal of Risk and Insurance 59, pp 575-600

Federal Reserve System [1995] Balance Sheets for the U.S. Economy, 1945-1994, Washington D.C.

Fletcher, L.P. [1966] Motivations Underlying the Mutualisation of Stock Life Insurance Companies Journal of Risk and Insurance, Vol 33, pp. 19-32.

Hemmings, R.A. and R.S. Seiler [1995] An Economically Viable Model for Insurers to Demutualize Best Review L/H, Nov. 1995, pp. 45-49

Hoyt, R.E. and R.D. Williams [1995] The Effectiveness of Catastrophe Futures as a Hedging Mechanism for Insurers Journal of Insurance Regulation, vol. 13, pp. 27-64

Hunter, J.R. [1994] Insuring Against Natural Disasters: Preventing, Planning and Panaceas Journal of Insurance Regulation, Vol. 12 \#4, pp. 467-485

Jaffee D. and T. Russell [1995] The Causes And Consequences of Rate Regulation in the Auto Insurance Industry, NBER Working paper No. 5245, and forthcoming in D. Bradford editor, The Property Casualty Industry, NBER/University of Chicago Press. 
Jensen, M. [1986] Agency Costs of Free Cash Flow, Corporate Finance, and Takeovers, American Economic Review, vol. 76 \#2, pp. 323-329

Kleindorfer, P. and H. Kunreuther [1996], "Challenges Facing the Industry in Catastrophic Risks, mimeo.

Mayers, D. and C. Smith [1981] Contractual Provisions, Organizational Structure, and Conflict Control in Insurance Markets, Journal of Business, Vol 54, pp. 407-434

Mayers, D. and C. Smith [1986] Ownership Structure and Control: The Mutualisation of Stock Life Insurance Companies, Journal of Financial Economics, Vol. 16, pp. 73-98.

Mooney, S. and L. Cohen [1991] Basic Concepts of Accounting and Taxation of Property / Casualty Insurance Companies Insurance Information Institute, New York.

Mooney, S. [1995] Presentation to Florida Academic Task Force on Hurricane Insurance, mimeo

Russell, T. [1988] Continuous Time Portfolio Theory and the Schwartz-Sobolev Theory of Distributions, Operations Research Letters, Spring.

Stein, Jeremy C. [1988], "Takeover Threats and Managerial Myopia,” Journal of Political Economy v96, n1:61-80.

Stein, Jeremy C. [1989], "Efficient Capital Markets, Inefficient Firms: A Model of Myopic Corporate Behavior.," Quarterly Journal of Economics v104, n4 (Nov 1989):655-669.

Venezian, E.C. [1985] Rate Making Methods and Profit Cycles in Property and Liability Insurance Journal of Risk and Insurance 52, pp. 477-500

Wallace, W.A. and J.M. Althoff [1994] Putting Away for a Rainy Day AICPA Case 94-08.

Wells, B.P., L.A. Cox, and K.M. Gaver [1995] Free Cash Flow in the Life Insurance Industry Journal of Risk and Insurance, vol. 62 \#1, pp. 50-66.

Zeckhauser, R. [1995] Insurance and Catastrophes The Geneva Papers on Risk and Insurance, 20, pp. 157-175. 